\title{
Evidence of the Presence of Genetically Modified Foods in the Sudano-Sahelian Zones of Cameroon
}

\author{
Djoulde Darman Roger ${ }^{1 *}$, Sobda Gone ${ }^{2}$ \\ ${ }^{1}$ Department of Agriculture, Livestock and Postharvest Technology, The Higher Institute of Sahel, \\ University of Maroua, Maroua, Cameroon \\ ${ }^{2}$ Institute of Agricultural Research for Development (IRAD), Maroua Research Center, Maroua, Cameroon \\ Email: ${ }^{\text {djoulde@gmail.com }}$
}

Received 5 January 2014; revised 5 February 2014; accepted 12 February 2014

Copyright (C) 2014 by authors and Scientific Research Publishing Inc.

This work is licensed under the Creative Commons Attribution International License (CC BY). http://creativecommons.org/licenses/by/4.0/

(c) (i) 0pen Access

\begin{abstract}
Concerns of Africans with transgenic foods and genetically modified organisms seem to have minor repercussions in general on the use and the commercialisation of these products on African markets and particularly in the northern sudano-sahelian zone of Cameroun. In this line, different crops (cotton, and maize) and some commercialized branded food products were sampled on local farms, markets and chops. Evaluation of the presence or absence of GMO was performed using labelling system, completed by the laboratory analysis using PCR methods combined with the electrophoresis. Amongst all collected items, sampled cotton of varieties IRMA L484, IRMA L457 and maize varieties ATP SRY (CHC 202), ECKEBIL (CLH 103), PAN 4P-767BR, PAN 5Q-433B and PAN 6Q-445B, were found to contain the foreign genetic material. Amongst processed commercialised brand products, 39 were found to contain genetically modified ingredients. Most were maize (glucose and syrup) and soya (lecithin).
\end{abstract}

\section{Keywords}

Food, GMO, Safety, Labelling, North Cameroun

\section{Introduction}

While in Asia and Latin America, the introduction of improved crop varieties and the application of scientific farming methods enabled food production to outstrip the population growth. In Africa, agricultural productivity

*Corresponding author. 
actually declined [1]. To face this, many advocates are in favour of the use of genetically modified foods [2]. Given the relative paucity of science and research capacities in Africa, it is not surprising that the arrival of genetic engineering and its application to farming techniques are in many places viewed with suspicion [3]. Absence of a scientific community does not mean that there is no constituency to lead the debate on the genetic modification (GM) technology. As a result, those debates quickly became drowned out by non-African voices. On the one hand, some US-based biotech companies were guilty of hyperbolic statements, presenting the GM technology as the key to unlocking the problem of food security in Africa [4]. On the other hand, a well-organized group of predominantly Europe-based non-governmental organizations, or NGOs, sometimes made exaggerated claims about the health adverse effect of these GMO [5]. Opposition to GMOs in Africa has manifested itself in several ways. African governments adopted tight restrictions on the international movement of GMO crops and seeds under the Cartagena Protocol, a UN Convention on biological diversity launched in 1996 [6]. The position against GMOs has acted as a brake on the use of GMcrop in Africa. Currently, only three African nations are known to produce biotech crops: South Africa, Egypt, and Burkina Faso. However, if the grown of GM crops seems momently stopped, this seems to not be the case of processed food containing as ingredient, all or partially GM material. The question risen here is therefore: are there any commercialized and unauthorized GM food in African Market? Specifically Cameroonian market? This paper aims at investigating the potential presence of GM food in the sudano-sahelian zone of Cameroon.

\section{Material and Methods}

\subsection{Sampling}

Maize and cotton seed samples were collected in private farms, markets and local agri-shop around Garoua and Maroua within the soudano-sahelian zone of Cameroon. Sampling of processed commercialized food was focused on branded based foods from known companies.

\subsection{Detection Methods}

The detection of branded commercialised food material was mainly based on labelling [7] [8]. The logic behind this were that most of commercialised food coming from European union containing GM material it's compulsory by the EU legislation to mentioned in the label that "this may contain genetically modified material" [9]. Concerning those coming from USA and Cananda were labelling is not compulsory, we used GM databases to check whether or not they may contain GM materials [9].

\subsection{Laboratory Analysis}

All samples were handled and brought to the laboratory, grounded and DNA material extracted as indicated by Meyer, [10]. Extracted DNA sequences were screened for modification by protein- and DNA-based methods using western blots, enzyme-linked immunosorbant assay, lateral flow strips, qualitative-, quantitative-, real-time- and limiting dilution-PCR methods as describe by Gachet, et al., [11], Hubner et al., [12] and Ahmed [9].

\section{Results and Discussion}

\subsection{Cotton Seeds}

Table one present results of laboratory analysis of cotton and maize seeds collected in the field from small farmer's reserves, researchers and local seed companies. Amongst seven collected cotton varieties sampled in the sudano-sahelian zone of Cameroon, two were positive for event-specific primers and probes for herbicide-tolerance Mon1445 and insect-resistant Mon531 by qualitative PCR detection. The source of the seed was found to be different from researcher to farmers. The interviewed researcher says that they have an official authorization from the government through the Cameroon National Biosafety Committee (NABIC) to conduct essay on cotton and they're using Bt cotton from Australia. However we have to mention that despite our effort to get a sample copy of this authorization document from the research institute, the cotton company in Cameroon (Sodecoton) and the NABIC, we didn't succeed to do so. The interviewed researcher also mentioned that there are two other local varieties under modification in South Africa, for herbicide-tolerance and insect-resistant. 
Theses varieties called IRMA L484 and IRMA L457 were selected by Cameroonian researchers and will be release in the field latest coming new agricultural campaign (2013-2014) but as shown they seem to already be in farmers' hands. Samples from farmers were said to have been continuously exchanging by Nigerian business men with cotton fiber since 3 year now. Meaning they're using these seeds every year since 2010 without any authorization. It has to be pointed that all collected samples from farmers present the same agro-morphological characteristics and seems to come from the same company. The others analyzed local varieties were found to contain no extra genes but both researchers and farmers mentioned that theses seeds are no more useful as the yield going decreased every year.

\subsection{Maize Seed}

We collected 10 varieties from farmers' reserves, research institute and from seed companies selling seed in Cameroon (ADER, SEMAGRY, SAVANA, TROPICACEM...) amongst which five were positive for Immunological assay for Cry1Ab (FlashkitTM from Biofords, Evry, France) and identification of genomic sequences adjacent to the 3'-integration site of event MON810 by RT-PCR analyses (Table 1). This seeds were said to be sown since 2005 in the field, two year after the ratification of Cartagena protocol by Cameroonian government and publication of Cameroonian law on biosecurity. The variety PAN 4P-767BR, PANNAR hybrids is said to be a YieldGard ${ }^{\circledR}$ (Bt) stalk borer resistance and Roundup Ready Plus ${ }^{\circledR}$ herbicide protection in one hybrid. Variety PAN 5Q-433B and PAN 6Q-445B are Roundup Ready ${ }^{\circledR}$ hybrids for weed control and YieldGard ${ }^{\circledR}$ or Bt hybrids which is said to offer protection against stalk borer damage. Both of these factors are said to minimize the potential yield loss of the crop. PANNAR's excellent genetics are available with built-in YieldGard ${ }^{\circledR}$ stalk borer resistance, Roundup Ready Plus ${ }^{\circledR}$ herbicide protection or with the stacked genes where both characteristics are combined in one hybrid.

\subsection{Processed Food}

Recorded food samples and accessed for GMO by labelling system are presented in the Table 2. We can notice

Table 1. Genetically modified field crops grown in northern Cameroon.

\begin{tabular}{|c|c|c|}
\hline Sample varieties/Origin & Methods & Result \\
\hline \multicolumn{3}{|c|}{ COTTON } \\
\hline IRCO 5028/IRAD/SODECOTON & \multirow{7}{*}{$\begin{array}{l}\text { Qualitative: western blots, enzyme-linked immunosorbant } \\
\text { assay } \\
\text { Quantitative: Event-specific primers and probes for } \\
\text { herbicide-tolerance Mon } 1445 \text { and insect-resistant Mon } 531 \text { by } \\
\text { qualitative PCR detection }\end{array}$} & - \\
\hline IRMA 1243/IRAD & & - \\
\hline IRMA 742/IRAD & & - \\
\hline IRMA 679/IRAD & & - \\
\hline IRMA BLT/IRAD & & - \\
\hline IRMA L484/IRAD/FIELD & & + \\
\hline \multirow[t]{2}{*}{ IRMA L457/Farmer/field } & & + \\
\hline & MAIZE & \\
\hline CMS 8704/IRAD & \multirow{10}{*}{$\begin{array}{l}\text { Qualitative: Immunological assay for Cry1Ab (FlashkitTM } \\
\text { from Biofords, Evry, France) lateral flow strips } \\
\text { Quantitative: Identification of genomic sequences adjacent to } \\
\text { the 3'-integration site of event MON810 by RT-PCR analyses }\end{array}$} & - \\
\hline CMS 8806/IRAD & & - \\
\hline CMS 8501/IRAD & & - \\
\hline CMS 9015/IRAD & & - \\
\hline SHABA/MINAGRI & & - \\
\hline ATP SRY (CHC 202)/MINAGRI & & + \\
\hline ECKEBIL (CLH 103)/MINAGRI & & + \\
\hline PAN 4P-767BR/Withe/PANAR & & + \\
\hline PAN 5Q-433B/PANAR & & + \\
\hline PAN 6Q-445B/Yellow/PANAR & & + \\
\hline
\end{tabular}

CMS: Cameroon Maize Series 
Table 2. Processed food sold in sudano-sahelian zone of Cameroon containing genetically modified ingredients.

\begin{tabular}{|c|c|c|c|}
\hline Item/brand name & Company/origin & $\begin{array}{l}\text { Genetically modified } \\
\text { ingredient }\end{array}$ & Source/database \\
\hline \multicolumn{4}{|c|}{ Baby Foods/Milk products } \\
\hline Bledina, Bledine, Galia & Bledina/France & & \\
\hline Babylait & Candia/Sodiaal & & $\begin{array}{l}\text { http://www.bledina.com/fr/duchampalassiette?ag=2\#/popin: } \\
\text { questionIndex }=2 ; \text { step }=2\end{array}$ \\
\hline Lactalis/Bridel & Carrefour & milk (use of GM Soya and & $\begin{array}{l}\text { http://www.sodiaal.fr/sodiaalfr/index.aspx?site=SODFR\&la } \\
\text { no=FR }\end{array}$ \\
\hline $\begin{array}{l}\text { Yoplait, Grand lait } \\
\text { LaitPilote }\end{array}$ & $\begin{array}{c}\text { Candia/Sodiaal } \\
\text { Celia }\end{array}$ & $\begin{array}{l}\text { Soya lecithin } \\
\text { Maize syrup } \\
\text { Maize glucose }\end{array}$ & $\begin{array}{l}\text { CERA. (2012). GM Crop Database. Center for Environ- } \\
\text { mental Risk Assessment (CERA), ILSI Research Founda- } \\
\text { tion, Washington D.C. }\end{array}$ \\
\hline $\begin{array}{l}\text { Guigoz (Evolia, lait } 1^{\mathrm{er}} \\
\text { age, lait 1er Age confort, } \\
\text { lait } 2^{\text {eme }} \text { age), Cereale } \\
\text { infantile }\end{array}$ & Nestle & Maize dextrose & $\begin{array}{l}\text { http://cera-gmc.org/index.php?action=gm_crop_database } \\
\text { www.agbios.com } \\
\text { www.greenpeace.fr }\end{array}$ \\
\hline
\end{tabular}

\begin{tabular}{|c|c|c|c|}
\hline \multicolumn{4}{|c|}{ Food enhancer } \\
\hline Lesieur & Campbell & $\begin{array}{l}\text { Rapeseed oil, sunflower oil, } \\
\text { glucose }\end{array}$ & www.greenpeace.fr, www.agbios.com, http://unclebens.fr, \\
\hline Sauces uncle Ben’s & Master foods & Corn flour and sunflower oil & http://www.maggi.fr, http://www.panzani.com/ \\
\hline Maggi, Buitoni & Nestlé & Tomatoes & $\begin{array}{l}\text { http://www.unclebens.ca } \\
\text { http://www.maggi.ca }\end{array}$ \\
\hline Panzani sauce spaghetho & Panzani & sunflower oil & \\
\hline \multicolumn{4}{|c|}{ Soup } \\
\hline Soupes Knorr & Unilever Best foods & $\begin{array}{l}\text { Sunflower oil and } \\
\text { soya bean oil }\end{array}$ & $\begin{array}{l}\text { http://www.telemarket.fr/dynv6/produit/29602000-panzani-s } \\
\text { auce-spagheto-pesto-basilic-frais-et-huile-d-olive-200-g.sht } \\
\underline{\text { ml www.greenpeace.fr }}\end{array}$ \\
\hline $\begin{array}{l}\text { Tomato puree double } \\
\text { concentrate, californian }\end{array}$ & Sainsbury’s & tomatoes & $\begin{array}{l}\text { http://www.meijer.com/s/amore-italian-tomato-paste-double } \\
\text {-concentrated-12-boxes-4-5-oz-ea//R-176789 } \\
\text { www.greenpeace.fr }\end{array}$ \\
\hline
\end{tabular}

Cake ingredients

Ancel Ancel Corn flour

http://www.cuisineaddict.com/achat-art-levure-chimique-ba king-powder-1-kg-278.htm?utm_source=shopbot\&utm_med $\underline{\text { ium=cpc\&utm term=278\&utm campaign=LeGuide\&ectran }}$ $\underline{\mathrm{s}=1}$

\begin{tabular}{|c|c|c|c|}
\hline Vahiné & DucrosMcCornick & $\begin{array}{l}\text { Sunflower oil and } \\
\text { soya bean oil }\end{array}$ & $\begin{array}{l}\text { http://www.vahine.fr/nos-produits/preparation-pour-gateaux/ } \\
\text { mi-cuits-chocolat-noir.html }\end{array}$ \\
\hline Pancake Syrup & $\begin{array}{c}\text { SDV } 16121 \\
\text { COGNAC CEDEX }\end{array}$ & Corn flour & http://www.auntjemima.com/aj_products/syrups/orginal.cfm \\
\hline \multicolumn{4}{|c|}{ Biscuits/Chocolate } \\
\hline Biscuits Bonne Maman & Andros & Baking powder & http://www.bonne-maman.com/biscuits.html \\
\hline Gallettes St Michel & Bahlsen St Michel & Corn flour & $\begin{array}{l}\text { http://forum.doctissimo.fr/nutrition/alimentation-sante/gelett } \\
\text { e-michel-sucre-sujet_164056_1.htm }\end{array}$ \\
\hline $\begin{array}{l}\text { Mikado, Pépito, Petit } \\
\text { Coeur }\end{array}$ & $\mathrm{Lu}$ & Soya lecithin & $\frac{\text { http://fr.openfoodfacts.org/additif/e322-lecithines }}{\text { http://www.nestleprofessional.com/france/fr/BrandsAndProd }}$ \\
\hline Nesquick & Nestle & Soya lecithin & ucts/Brands/NESQUIK/Pages/NESQUIK_Plus_Boite.aspx? \\
\hline Milk Chocolate/Mambo & Chococam & & UrlReferrer=https\%3a\%2f\%2fwww.google.cm\%2f \\
\hline \multicolumn{4}{|c|}{ Cereals } \\
\hline $\begin{array}{c}\text { Farine de maïs } \\
\text { (MASECA) Masa } \\
\text { instantanta de maiz } \\
\text { Maïs à Eclater au } \\
\text { Four-Pop corn/Newmans } \\
\text { Own }\end{array}$ & $\begin{array}{l}\text { SDV } 16121 \\
\text { COGNAC CEDEX } \\
\text { USA/France }\end{array}$ & corn flour & $\begin{array}{l}\text { http://www.mexgrocer.com/2440.html } \\
\text { http://fr.openfoodfacts.org }\end{array}$ \\
\hline BeanFeast & & Corn syrup, soya lecithin & $\begin{array}{l}\text { http://www.britstore.co.uk/Ready-Meals-Batchelors-Instant- } \\
\text { Snacks/c500_950/p8154/Beanfeast-Bolognese-Style-120g/pr } \\
\text { oduct_info.html }\end{array}$ \\
\hline
\end{tabular}




\begin{tabular}{|c|c|c|c|}
\hline Butterfinger & Nestlé & Corn flour & http://www.butterfinger.com/ \\
\hline Post Oreo’s & $\begin{array}{l}\text { Marshmalow/ } \\
\text { France }\end{array}$ & Corn and soya flour & $\begin{array}{l}\text { http://idsgn.org/posts/ritz-and-oreo-go-retro/ } \\
\underline{\text { http://fr.openfoodfacts.org }}\end{array}$ \\
\hline \multicolumn{4}{|c|}{ Oils } \\
\hline Huile de Soja MAUREL & & Soya bean & \\
\hline Alba/Huile de soja & Huilor & Soya bean & $\begin{array}{l}\text { http://www.greenpeace.fr/detectivesOGM/magasin_humain. } \\
\text { php }\end{array}$ \\
\hline $\begin{array}{l}\text { Huile vegetable pour } \\
\text { assaisonnement }\end{array}$ & & Soya bean & http://fr.openfoodfacts.org \\
\hline
\end{tabular}

that most of the proceed food are from abroad except Chocolate bars from Chococam (Mambo) and biscuits from Ok Foods. The main origin is respectively France, United States and Canada. The main ingredients are maize glucose, soya lecithin, and lesser extend animal products coming from animals feed with genetically modified material such as maize flour and gritz, soya flour and cotton derivatives.

\section{Discussion}

Among the pioneers in African countries, Cameroon created in 1997 a National Biosafety Committee (NABIC) whose mission was to organize and coordinate the preparation of a national biosafety legislation [13]. This committee consists of 23 members, representing eight departments, four universities (through their faculties), the National Quality Control Laboratory, the center of Biotechnology Information, the World Wide Fund for Nature (WWF) and a representative agri-food industry. No civil organization is part of this committee, but some NGOs participate as observers in different sessions. The NABIC conducted several meeting under the auspice of the minister in charge of environment. However as shown through this study, there are evidences of genetically modified food beside national territory. It may be noted that the technical services designated to work with the NABIC within each department are not always the most appropriate. Cameroon has ratified the Cartagena Protocol in February 2003, the country also actively participated in the negotiation process of this protocol. The National Biosafety Committee finalized Cameroonian legislation early 2003 and after revision, the text was adopted by the National Assembly in April 2003. Cartagena protocol is a law that regulates biological manipulations in third world countries. The main objective of this agreement is to organize and helps poor countries to adopt new genetically engineered technology, taking into account their specific needs. The principle of action, is to favors precaution and prevention but not to open opportunities for technical support and funding needed to carry out development projects concerning biosafety. Therefore, the revision of the law by lawyers not specialist of biosafety issues has focused technical aspects of the text in favor of purely administrative considerations, further complicating its application. This law still requires a lot of work because most of the content refers to implementing regulations that are not yet prepared.

Following their statements, local authorities adopt a positive attitude towards the development of biotechnology, probably attracted by the prospect of food self-sufficiency. The primary agricultural sector employs $65 \%$ of the active population and contributes $45 \%$ of GDP. The main food crops are maize, millet, sorghum, rice, yams, cassava and plantain. The main export crops which were introduced in the country during the colonial period, are cocoa, coffee, cotton and rubber [14]. To cover its deficits, Cameroon imports number of products, including corn (Maize) from United States and South Africa, and soybean meal which itself comes from Canada [15]. These imports are not subject to special precautions (isolation or labeling) so retailers and importers are not subject to any constraint [16]. This can explain the presence of all detected and founded genetically modified organism on market and field in northern Cameroon. Officially, no research program in Cameroon focuses on GMOs. However, as mentioned latter on, interviewed researcher in charge of cotton selection from the Institute of Agricultural Research for Development (IRAD) indicate that the have authorization to conduct such research within the country on genetically modified cotton, but we didn't succeed to see or get a copy of this document in other to discuss about its content. Some laboratories in the country are able to conduct plant tissue culture and some researchers have already been trained in transgenes techniques [17] [18]. However, there is still no national body responsible for carrying out investigations and inspections in the field as specified in the legislation. In 2002, some seed companies (SeedCo Zimbabwe Ltd and Monsanto) conducted field trials with maize, but no 
source of information could allow us to determine if they were genetically modified or not [19]. However the presence of some genetically modified varieties in the field used by farmers indicate that they would have buy them some were as farmer don't yet have technology require to modify plants. As also mentioned earlier some of these seed were collected directly by us from local retailer representing some international companies' producers of genetically modified seeds. The concerns about safety of our food are becoming a tremendous problem within the central African countries. Even if some of these countries succeeded to induce the adoption of a moratorium for the probate of transgenic products which can be commercialise and use as human food, this seems may be regulated. This is particularly important at the moment when some countries, because of suspicious worry in regard with the safety of transgenic crops, refused food aids containing genetically modified organisms. The Cameroon last riot of hunger may also be key factor concerning genetically modified organism utilisation in Cameroon. This situation is reinforced by difficult agro-ecological conditions, requiring the use of seeds says to be "adapted to dough" or "resistant to bugs" manly introduced in the area by the "actors of the development" (including government researchers). This situation got a support on the laxity, the carelessness or often to the ignorance of authorities in charge of consumer protection.

Cameroon by its place in agro-economic landscape in Africa is a good place to conduct a "critical analysis" of the situation as other countries in the Central African sub-region such as Chad, Gabon, Central African Republic, Congo and Equatorial Guinnee would be in a similar dynamic regarding the use of these new technologies resulting from genetic engineering but with their own specificity related to the socio-economic context of each country.

\section{Conclusion}

This paper tempts to present the situation of transgenic foods in the soudano-sahelian zone of Cameroon. Potential transgenic foods found on the market and on the fields in farming zone are described and listed. Theirs sources are discussed. Failures in the legislation and their applications are also highlighted. The necessity to achieve more deepened studies on transgenic foods and GMO in North Cameroon is obvious. The incriminated products, the national, regional and international movements, the form of commercialisation and the use of these foods remain unknown at present. This probably explains few attentions brought to this topic. Several ways of intervention must be proposed for the updating of the existing regulation backing the assessment and the management of risks, as well as the decision making concerning the management of genetically modified crops in the field in soudano-sahelian zone of Cameroon. We hope that these results could contribute to developing the further mix operation of the research and the investigation concerning genetically modified organisms in the sudano-sahelian zone of Cameroon.

\section{References}

[1] Cooke, J.G. and Downie, R. (2010) African Perspectives on Genetically Modified Crops Assessing the Debate in Zambia, Kenya, and South Africa, A Report of the Center for Strategic and Inter-National Studies (CSIS) Global Food Security Project, 30 p.

[2] Klintman, M. (2002) The Genetically Modified (GM) Food Labelling Controversy Ideological and Epistemic Crossovers. Social Studies of Science, 32, 71-91. http://dx.doi.org/10.1177/0306312702032001004

[3] Coleman, I., (2012) Genetically Modified Crops and Africa’s Agricultural Potential Posted in Economic Development, Sub-Saharan Africa, Technology and Development, Women and Development Share.

[4] Azadi, H. and Ho, P. (2010) Genetically modified and organic crops in developing countries: A review of options for food security. BiotechnologyAdvances, 28, 160-168. http://dx.doi.org/10.1016/j.biotechadv.2009.11.003

[5] Bakshi, A. (2003) Potential adverse health effects of genetically modified crops. Journal of Toxicology and Environmental Health Part B: Critical Reviews, 6, 211-226. http://dx.doi.org/10.1080/10937400306469

[6] Qureshi, A.H. (1996) The Cartagena Protocol on Biosafety and the WTO-Co-Existence or Incoherence? Journal of International Environmental Law and Policy, 7, 12-15.

[7] Caswell, J. (2000) An Evaluation of Risk Analysis as Applied to Agricultural Biotechnology (with a Case Study of GMO Labeling). Agribusiness, 16, 115-123. http://dx.doi.org/10.1002/(SICI)1520-6297(200024)16:1<115::AID-AGR9>3.0.CO;2-M

[8] Herrick, C.B. (2005) Cultures of GM’: Discourses of Risk and Labelling of GMOs in the UK and EU. Area, 37, 286294. http://dx.doi.org/10.1111/j.1475-4762.2005.00632.x 
[9] Ahmed, F.E. (2002) Detection of Genetically Modified Organisms in Foods. TRENDS in Biotechnology, 20, 215-223. http://dx.doi.org/10.1016/S0167-7799(01)01920-5

[10] Meyer, R. (1999) Development and Application of DNA Analytical Methods for the Detection of GMOs in Food. Food Control, 10, 391-399. http://dx.doi.org/10.1016/S0956-7135(99)00081-X

[11] Gachet, E., Martin, G. G., Vigneau, F. and Meyer, G. (1998) Detection of Genetically Modified Organisms (GMOs) by PCR: A Brief Review of Methodologies Available. Trends in Food Science \& Technology, 9, 380-388. http://dx.doi.org/10.1016/S0924-2244(99)00002-3

[12] Hubner, P., Waiblinger, H.U., Pietsch, K. and Brodmann, P. (2001) Validation of PCR Methods for Quantitation of Genetically Modified Plants in Food. Journal of AOAC International, 84, 1855-1864.

[13] Fombad, C.M. (2013) Some Reflections on the Prospects for the Harmonization of International Business Laws in Africa: OHADA and Beyond. Africa Today, 59, 50-80. http://dx.doi.org/10.2979/africatoday.59.3.51

[14] Shepherd, A.W. and Farolfi, S. (1999) Export Crop Liberalization in Africa: A Review (No. 135). Food and Agriculture Organization, Rome.

[15] Dimaranan, B.V. and Mcdougall, R.A. (2006) Guide to the GTAP Data Base. In: Dimaranan, ed., Global Trade, Assistance, and Production: The GTAP6 Data Base, Center for Global Trade Analysis, Purdue University, West Lafayette, 245 Pages.

[16] Arvanitoyannis, I.S., Choreftaki, S. and Tserkezou, P. (2005) An Update of EU Legislation (Directives and Regulations) on Food-Related Issues (Safety, Hygiene, Packaging, Technology, GMOs, Additives, Radiation, Labelling): Presentation and Comments. International Journal of Food Science \& Technology, 40, 1021-1112. http://dx.doi.org/10.1111/j.1365-2621.2005.01113.x

[17] Kenne, T. (2010) Les Biotechnologies en Afrique centrale: le cas du Cameroun, lecodonitiateur Tags: Pub congo nature article travail cadre afriquepaysage texte. http://lecodonitiateur.centerblog.net/15-les-biotechnologie-en-afrique-centrale-le-cas-du-cameroun

[18] Racovita, M., Obonyo, D.N., Abdallah, R., Anguzu, R., Bamwenda, G., Kiggundu, A. and Craig, W. (2013) Experiences in Sub-Saharan Africa with GM Crop Risk Communication: Outcome of a Workshop. GM Crops and Food: Biotechnology in Agriculture and the Food Chain, 4, 19-27. http://dx.doi.org/10.4161/gmcr.22488

[19] Rivera-Dominguez, M. and Tiznado-Hernandez, M.E. (2013) Utilization of Omics Technology to Analyze Transgenic Plants. In: Debmalya B., Vasudeo, Z. and Vasco, A., Eds., Omics: Applications in Biomedical, Agriculture and Environmental Sciences, CRC Press, Boca Raton, 399-437. 